\title{
Az impaktfaktor és akiknek nem kell*
}

\author{
Schubert András \\ MTA Könyvtár és Információs Központ, Tudománypolitikai és Tudományelemzési Osztály, Budapest
}

\begin{abstract}
Az impaktfaktort 1976-os bevezetése óta folyamatosan bírálják és dicsőítik. Ebben a cikkben a szerző főként azt tekinti át, hogy az impaktfaktor, illetve annak használata elleni fenntartások és ellenvetések voltaképpen mit kifogásolnak. Ezeket közelebbról áttanulmányozva ugyanis sokszor kiderül, hogy a bírálatok gyakran nem az impaktfaktor specifikus lényegét illetik, hanem sokkal általánosabb aggályokat fogalmaznak meg, vagy pedig felszíni technikai részleteket, könnyen orvosolható fogyatékosságokat vagy a hibás használatból származó következetlenségeket kérnek számon. Orv. Hetil., 2015, 156(26), 1065-1069.
\end{abstract}

Kulcsszavak: tudománymetria, impaktfaktor

\section{The impact factor and those who dislike it}

Since its introduction in 1976, the impact factor is permanently a subject of both criticism and glorification. This paper gives an overview on what actually the reservations and objections attack. A closer look often reveals that the criticisms are not against the specific substantial features of the impact factor. They may formulate much more general doubts or, on the other hand, superficial technical details, easily remediable flaws or inconsistensies resulting erroneous use.

Keywords: scientometrics, impact factor

Schubert, A. [The impact factor and those who dislike it]. Orv. Hetil., 2015, 156(26), 1065-1069.

(Beérkezett: 2015. május 15.; elfogadva: 2015. június 5.)

$\mathrm{Az}$ „impact factor” kifejezés az idézettséggel kapcsolatos kontextusban először Eugene Garfield egy 1955-ös Science-cikkében fordul elő [3]. Ebben az írásában, amelyben Garfield az akkor még csak előkészületben lévő Science Citation Index (SCI) elvi alapvetését fogalmazza meg, az „impact factor” az egyes kutatók teljes idézettségét jelenti, ami a szerző szerint a publikációk számánál jellemzőbb mutatója lehet a kutatók tudományos hatásának, „impact”-jának.

Az SCI Journal Citation Reports (JCR) 1976-os első megjelenését előkészítő Science-cikkben [4] már a folyóiratokra vonatkozó és a későbbiekben közismertté vált definíció található: az impaktfaktor egy folyóirat előző kétévi cikkeire a tárgyévben kapott idézeteinek átlagos száma.

A JCR vitathatatlan szakmai és üzleti sikere mellett már az első JCR impaktfaktorlisták nyilvánosságra hozatala után nem sokkal jelentek meg erősen kritikai hang- vételü cikkek. Csak példaként néhány jellemző cím: „Is the impact factor a meaningful index for the ranking of scientific research journals?" vagy "The citation impact factor - another dubious index of journal quality".

Ez a kettősség végigkíséri az impaktfaktor immár jó négy évtizedes történetét. Az ezzel kapcsolatos polémiákban jól tükröződik az a tény, hogy a tudománymetria egy igen széles sávot fed le a kemény kvantitatív tudományok és a puha társadalomtudományok közötti spektrumon. A matematikai (vagy legalábbis annak tetsző) érvelés és az intuitív, néha szenvedélyes meggyőzés egyaránt helyet kap ezekben a vitákban, amelyekben - részben ezért is - a konszenzus esélye igen csekély.

A jelen írás semmiképpen nem kíván igazságot tenni vagy akár csak állást foglalni az egymásnak feszülő nézőpontok között. A kérdéskörnek csak egy szúk szeletét vizsgálnám meg kicsit alaposabban: azt, hogy az impakt-

*A cím Lukács György híres-hírhedt dolgozata [1] címének parafrázisa (részletesebben lásd [2]). 
faktor, illetve annak használata elleni fenntartások és ellenvetések voltaképpen mit kifogásolnak. Ezeket közelebbről áttanulmányozva ugyanis sokszor kiderül, hogy a bírálatok gyakran nem az impaktfaktor specifikus lényegét illetik, hanem sokkal általánosabb aggályokat fogalmaznak meg, vagy pedig felszíni technikai részleteket, könynyen orvosolható fogyatékosságokat vagy a hibás használatból származó következetlenségeket kérnek számon.

\section{Egy kis kitérő: az impaktfaktorról szóló irodalom}

Az impaktfaktorral foglalkozó irodalom nem csekély. A Web of Knowledge-ból származó legfrissebb adatok szerint 1978-2015 között több mint 2000 olyan cikket találunk, amelynek a címében szerepel az „impaktfaktor” kifejezés. Ezek a cikkek nem is maradtak visszhangtalanok: átlagosan körülbelül 8 idézetet kaptak; a cikkhalmaz h-indexe 48. A tendencia egészen a legutóbbi évekig erőteljesen növekvő, 2012 után tapasztalható valamelyes megtorpanás (1. ábra).

Érdekes megnézni, hogy milyen folyóiratokban jelennek meg az impaktfaktorral kapcsolatos cikkek. Az egyes folyóiratokat tekintve - egyáltalában nem meglepő módon - a Scientometrics vezet 90 cikkel. Két multidiszciplináris folyóirat, indiai Current Science (44) és a Nature (36) követi. Ha azonban a szakterületi összesített adatokat tekintjük, akkor - némi meglepetésre - a klinikai orvostudományi folyóiratok vannak nagy fölényben (az összes cikk 47\%-ával) a társadalomtudományi (elsősorban természetesen az információtudományi; 16\%) és a multidiszciplináris (6\%) folyóiratok előtt. Az egyes szakterületeken megjelent összes cikk arányait is figyelembe véve ez úgy módosul, hogy a multidiszciplináris folyóiratokban a legnagyobb a relatív érdeklődés az impaktfaktorral foglalkozó cikkek iránt, ezt követik a társadalomés az orvostudományok körülbelül azonos arányszámmal, messze megelőzve például a fizikát vagy a kémiát. A legkisebb az impaktfaktor iránti érdeklődés a matematika és a számítástudományok területén.

$\mathrm{Az}$ impaktfaktorral foglalkozó cikkek címében viszonylag ritkán jelenik meg egyértelmű pozitív vagy negatív állásfoglalás. A cikkek legtöbbje valamely ország vagy szakterület folyóiratainak, vagy egy konkrét folyóiratnak az impaktfaktorát elemzi.

A helytelen használatra utaló „misus*”, „mislead*”, illetve hasonló kifejezések körülbelül 30 alkalommal, az elfogultság („bias*”) 13 alkalommal, a javításra való igény, illetve törekvés ( „improv* ”) 26 alkalommal fordul elő a cikkek címében.

Ha azonban az impaktfaktorral foglalkozó legidézettebb cikkeket tekintjük, közöttük érthető módon „feldúsulnak" a kritikus hangvételü, illetve a jobbító törekvésű cikkek $[5,6,7,8]$. A következő pontban részben ezeknek a cikkeknek a nyomán kíséreljük meg áttekinteni az impaktfaktorral szembeni ellenvetéseket és azok jogosságát.

\section{Az impaktfaktorral szembeni ellenvetések}

A legidézettebb cikkben (e cikk megírásáig a Web of Knowledge szerint 694 idézetet kapott) Per O. Seglen [5] ellenvetéseit négy pontban foglalja össze:

1. Az impaktfaktor használata elfedi az egyes cikkek idézettsége közötti különbségeket.

2. A folyóiratok impaktfaktora olyan technikai tényezőktől is függ, amelyek nincsenek kapcsolatban a cikkek tudományos minőségével.

3. A folyóiratok impaktfaktora függ a kutatási területtól.

4. Az egyes cikkek idézettsége határozza meg a folyóiratok impaktfaktorát és nem fordítva.

E pontok igazságtartalmát nem lehet vitatni, de véleményem szerint sem egyenként, sem összességükben nem szolgálnak alapul egy sommás elutasításhoz.

Ad 1. Ez minden átlagra igaz. Ezért találták ki a statisztikusok például a szórás fogalmát.

Ad 2. Itt a szerző olyan „technikai tényezőket” sorol fel (avulási idő, nyelv stb.), amelyek minden idézettségi vizsgálatot befolyásolnak. Ezek figyelembevétele lehetséges, és minden komoly elemzésben meg is történik.

Ad 3. Ez is minden idézettségi vizsgálatra igaz, és természetesen figyelembe veendő.

Ad 4. Erre éppen a szóban forgó cikk egy kitünő ellenpélda, mert ha történetesen nem a $B M J$-ben jelenik meg, akkor egészen bizonyosan nem kapott volna ennyi idézetet.

Mindezzel együtt tökéletesen egyet lehet érteni a szerzővel abban, hogy a JCR-ből kikeresett IF-értékek önmagukban nem alkalmasak a kutatási teljesítmény értékelésére. Az eszköz hibás használatának a bírálata jogos, de ennek nem szabadna az eszköz használatának teljes elutasításához vezetnie.

A hasonló kritikai hangvételü cikkek áttanulmányozásával összeállíthatjuk az impaktfaktorral szembeni ellenvetések egy általánosabb tipológiáját.

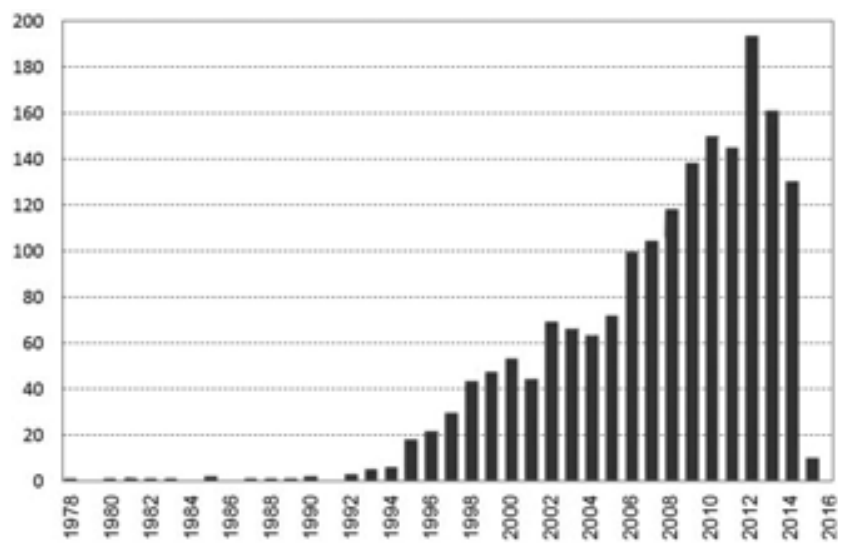

1. ábra $\mid$ A címükben az „impaktfaktor” kifejezést tartalmazó cikkek száma évenként (Forrás: Web of Science) 
- Az idézettségen vagy még általánosabban, a tudománymetriai módszereken alapuló értékelési eljárások elutasítása.

- Az átlag, mint egy sokaságot jellemző mutatószám, alkalmasságának kétségbe vonása.

- A publikációs és idézettségi időablakok bírálata.

- A szakterületi különbségek figyelmen kívül hagyása.

- A folyóirattípusok közötti különbségek figyelmen kívül hagyása (például review folyóiratok).

- A dokumentumtípusok közötti különbségek figyelmen kívül hagyása.

- Az önidézetek szerepének figyelmen kívül hagyása.

- Az impaktfaktornak nem folyóiratok értékelésére való felhasználása (egyének, intézmények stb.), illetve a felhasználás módjának megkérdőjelezése.

Újból csak azt mondhatjuk, hogy az ellenvetések nagy része nem teljesen megalapozatlan, de érvényességüket, relevanciájukat ugyanúgy konkrétan egyes esetekre lehet csak megvizsgálni, mint az impaktfaktor (vagy annak valamilyen módosított változata) használata melletti érveléseket.

Figyelemre méltó szempontra hívják fel a figyelmet a „Folyóirat-impaktfaktor: egy hibásan elnevezett, félreértelmezett és rosszul használt mérôszám" címü cikk [8] szerzői. Véleményük szerint „a mérőszámot tényleges szerepe szerint kellene megnevezni, ami pusztán egy adott időszakra vonatkozó idézettségi index, és semmi több."

Ezzel a véleménnyel összhangban Vinkler például következetesen Garfield-faktornak nevezi a JCR-ben közölt értékeket [9]. Ez egyrészt tiszteletadás az impaktfaktort megalkotó Eugene Garfield elött, másrészt lehetőséget ad arra, hogy világos különbséget tegyünk a JCR-ben közölt értékek esetlegességei és a mutatószám létrehozásakor lefektetett elveket esetleg jobban megvalósító, mondhatni, „fejlettebb” impaktfaktorok között.

\section{Az impaktfaktor módosított változatai}

Az irodalomban az impaktfaktornak több száz módosított (a szerzőik szerint többnyire „javított”) változatát találhatjuk. Ezek legnagyobb része nem több, mint ötletelés: az impaktfaktor valamilyen vélt vagy valódi fogyatékosságát valamilyen korrekciós formulával igyekeznek kijavítani, és ezt többnyire valamilyen ad hoc példán illusztrálják.

Az igyekezet általában két ponton fut zátonyra.

1. Nem létezik egyetemesen „jó” vagy „rossz” mutatószám, ezek a minősítések mindig csak valamilyen konkrét alkalmazás, feladat kapcsán értelmezhetők. Ezért a „javítások”, ha egyáltalán, csak az alkalmazások meghatározott korlátai között érvényesek, és ezekre az érvényességi korlátokra a legritkább esetben történik megfelelő utalás.

2. Az adott javító szándékú cikkben illusztrációként közölt példán kívül a módosított mutatószámok más folyóiratokra nem hozzáférhetőek, sokszor még azok rep- rodukciója is alig lehetséges. Ezért a javított mutatószámok gyakorlati alkalmazása még az érvényességi korlátokon belül is további - szinte leküzdhetetlen - akadályokba ütközik.

Ezen a helyen jegyezhetjük meg, hogy az impaktfaktor (vagy az egyértelmüség kedvéért, Vinklert követve, a Garfield-faktor) - bár az évtizedek alatt sokoldalúan, tudományos alapossággal körüljárt fogalommá lett - alapvetően mégis csak egy kereskedelmi termék, amelyet jelenlegi gazdája, a Thomson-Reuters üzleti alapon bocsát a felhasználók rendelkezésére. Óhatatlanul felvetődik a kérdés, hogy vajon a módosított változatok szerzőit pusztán a jobbítás idealista szándéka vagy esetleg az üzleti siker reménye is vezérli.

Természetesen pusztán az a tény, hogy valami üzleti termék, nem kérdőjelezi meg a használhatóságát, alkalmasságát. Az orvosi gyakorlatban kitűnő példái ennek a gyógyszerek. De miként a gyógyszerek esetében az orvosnak, a tudománymetriai mutatószámok esetében az elemzőnek, illetve a döntéshozónak kell kiválasztania, hogy egy adott esetben melyik konkurens termék használata a célravezető.

Konkrét példaként csak azok közül említenék néhányat, amelyek az ötlet szintjén túljutottak, és valamilyen módon hozzáférhetôvé váltak a nagyobb nyilvánosság számára is.

Influence Weight. A Francis Narin vezette Computer Horizons Inc. (CHI) fejlesztése volt az ISI Science Citation Index adatbázisának adatai alapján $[10,11]$. A projekt a financiális támogatás és a CHI-ISI együttmúködés megszûntével abbamaradt.

Prestige Factor. A PrestigeFactor.com vállalkozás 2001-ben kezdett híveket, sőt előfizetőket toborozni adatbázisára, amely a JCR impaktfaktorának lényeges meghaladását ígérte. Valójában a módosítások marginálisak és kétséges értéküek voltak, amire a szakmai vélemények hamar rámutattak [12]. A vállalkozásnak azonban nem annyira a szakmai kritika, mintsem az vetett véget, hogy az ISI milliós perrel fenyegette meg adatainak jogtalan használata miatt.

Euro-Factor. Az „eurofória” jegyében fogant 2002ben a VICER osztrák kiadó kezdeményezése egy európai folyóiratindikátor-adatbázis létrehozására a JCR amerikai túlsúlyát kompenzálandó. A hangzatos szlogenek mögött kevés tartalom volt [13].

Ötéves impaktfaktor. Ezt a mutatószámot a ThomsonReuters Web of Knowledge Journal Citation Reports adatbázisa 2007-ben építette bele mutatószámrendszerébe. A Garfield-faktorhoz hasonlóan ez is átlagos idézettség, amelyet ebben az esetben a tárgyévet megelőző öt év publikációira a tárgyévben kapott idézetek alapján számítunk ki. Ez volt a válasz azokra a kritikákra, amelyek a kétéves publikációs időszak elégtelenségét hangsúlyozták.

Eigenfactor Metrics. Az Eigenfactor Score és az Article Influence Score mutatószámok ugyancsak 2007-ben kerültek a Journal Citation Reports mutatószámrendszeré- 
be. Feltünnek bennük a Narin-féle Influence Weight számításának elemei, de fó újdonságának azt hirdeti, hogy a kiszámításuk során a folyóirat-önidézeteket eliminálják. E gondolat hasznossága nehezen igazolható.

SCImago Journal Rank (SJR). A SCImago az Elsevier Scopus adatbázisa alapján szerkesztett tudománymetriai adatbázis [14], amelyet Felix de Moya Anegón, a Granadai Egyetem (Spanyolország) professzora kezdeményezett 1996-ban. Az SJR közvetlenül a Google PageRank mintájára készült; ezzel együtt a Narin-féle Influence Weight leszármazottjának is tekinthető.

b-index. A Jorge Hirsch által az egyéni kutatói teljesítmény mérésére javasolt h-index használhatósága messze túlmutat szerzője eredeti szándékain. A folyóiratok értékelésére való különleges alkalmasságát Hirsch cikkének megjelenési évében mutattuk be először [15]. A mutatószám azáltal válhatott egy jó ötletnél többé, hogy a SCImago [14] bevette sztenderd folyóirat-mutatószámai közé.

SNIP. A SNIP (Source-Normalized Impact per Paper) mutatószámot Henk Moed fejlesztette ki, aki korábban a Leideni Egyetem Tudomány- és Technológiaelemzési Központjának (CWTS) munkatársa, majd az Elsevier vezető elemzője volt [16]. A SNIP kimondottan a szakterületek közötti összehasonlítás eszköze. A folyóiratok SNIP-értékeit a CWTS adatbázisában találhatjuk meg [17].

Mindezeket a változatokat azért is soroltam fel, hogy megmutassam: az impaktfaktor ma már koránt sincsen monopolhelyzetben, és használata akkor és csakis akkor indokolt, ha sajátosságai előnyösnek látszanak valamely konkrét esetben. Ilyen esetek viszont lehetségesek, vannak, és bizonyára sokáig lesznek is.

\section{Az impaktfaktor alkalmazása a kutatásértékelésben}

Az impaktfaktor kutatásértékelési szerepével kapcsolatos kétségek három szinten fogalmazhatók meg.

1. Alkalmasak-e a tudománymetria módszerei (publikációk, idézetek statisztikai elemzése) arra, hogy a tudományos kutatás minőségét, színvonalát illető érdemi információkkal járuljon hozzá a kutatási teljesítmény értékeléséhez?

2. Egy folyóiratok jellemzésére kidolgozott mutatószámnak van-e keresnivalója olyan esetekben, amikor az értékelés tárgya nem folyóirat, hanem például intézmény, kutatócsoport vagy esetleg egyén?

3. Az impaktfaktor (Garfield-faktor) vagy valamelyik másik folyóirat-mutatószám alkalmasabb-e az értékelési feladatban való felhasználásra?

A három kérdés nyilvánvalóan hierarchikusan követi egymást. Ha valamelyik kérdésre a válasz „nem”, akkor a következő kérdés(ek) irrelevánsakká válnak.
Ad 1. Az első kérdés könyvtárnyi irodalmának taglalásába most nem bocsátkoznék. Érdekes megfigyelni, hogy a legkidolgozottabb, rendszeresen használt értékelési rendszerek (például az Egyesült Királyság vagy Ausztrália egyetemi értékelési rendszerei) az elmúlt évtizedekben bizonyos periodicitást mutattak a tudománymetriai módszerek elfogadását (sőt néha túlértékelését), illetve elutasítását illetően. Az Egyesült Királyság ilyen rendszere, a Research Evaluation Framework (REF; a korábbi Research Assessment Exercise [RAE] utóda) 2014-es álláspontja szerint „az idézettségi információk nem kellőképpen robusztusak ahhoz, hogy képletszerüen vagy elsődleges mutatószámokként használjuk őket, de ezeknek az adatoknak tájékoztató és segítő szerepük lehet a szakértői vélemények kialakításában” [18]. Kellően semmitmondó, de nem egészen haszontalan álláspont.

Ad 2. A kérdés egy aspektusát már Seglen cikke [5] kapcsán érintettük. Bár igaz az, hogy egy folyóiratban megjelent cikkek idézettsége határozza meg a folyóirat impaktfaktorát és nem fordítva, de vitathatatlan, hogy a kiemelkedő impaktfaktorú folyóiratok a cikkek kiválasztási mechanizmusával, a bírálati rendszer szigorúságával igyekeznek fenntartani a megjelent cikkeik iránti érdeklődést, ezen keresztül az idézettséget. Ezért aztán az ilyen folyóiratokban való megjelenés már eleve egy bizonyos elismerést jelent.

Természetesen egy bizonyos idő eltelte után egy cikknek már magának kell bizonyítani érdemeit. A tudománymetria keretei között ezt a kapott idézetekkel érheti el. Ennek megfelelően a folyóirat-mutatószámok (így az impaktfaktor) a kutatásértékelésben kettős szerepet játszanak.

„Impaktfaktor a számlálóban”: Ez a viszonylag friss (körülbelül az elmúlt 2-3 évben megjelent) cikkekre vonatkozik: az impaktfaktor ilyenkor a publikációs stratégia ambiciózusságának, illetve a friss publikációk jövőben várható idézettségének megítélését szolgálja.

„Impaktfaktor a nevezőben”: Ez a régebbi cikkekre vonatkozik: ilyenkor az impaktfaktor az elvárt idézettség mércéjéül szolgál, amihez a ténylegesen kapott idézettséget hozzámérhetjük.

Egy nagy impaktfaktorú folyóiratban megjelent cikk szerzője tehát a megjelenést követően egy ideig joggal élvezheti a megelólegezett bizalmat, de azután az elóleget vissza kell fizetni, a nagyobb impaktfaktornak megfelelő nagyobb idézettséget kell elérni ahhoz, hogy teljesítse az elvárásokat.

Ad 3. Azt, hogy valamelyik mutatószám alkalmasabb-e egy másiknál, mindig csak egy konkrét értékelési feladat kapcsán lehet eldönteni. (Akkor sem mindig könnyü.) Semmi ok nincs azt feltételezni, hogy ne legyen olyan feladat, amikor az impaktfaktor lenne a legalkalmasabb mutatószám, de bizonyára sok esetben nem az. Ezért kell egy minél szélesebb eszköztár, és nagy elemzői tapasztalat az értékelési feladatok eredményes elvégzéséhez. 


\section{„San Francisco Declaration on Research Assessment"}

A DORA néven elhíresült dokumentumot [19] 155 egyéni és 82 intézményi aláíró hitelesítette az Amerikai Sejtbiológiai Társaság (ASCB) éves konferenciáján San Franciscóban 2012. december 16-án. A későbbiek során a deklarációhoz több ezer egyéni és intézményi aláró is csatlakozott. A kétségkívül alapvetően jó szándékú kezdeményezés hangsúlyosan fellép az impaktfaktornak a kutatás értékelésében való belytelen használata ellen. A deklaráció szövegében szereplő használati mód - vagyis az, hogy az impaktfaktort az egyes cikkek, illetve szerzőik közvetlen értékmérőjéül használjuk - ugyanis egyértelmúen helytelen, amint remélhetően az e cikk korábbi részeiből is világosan kiderül.

Sajnálatosan - de nem egyedülálló módon - a jó szándékú intés a későbbiekben dogmává merevülve az impaktfaktor (és részben a vele rokon mutatószámok) teljes diszkreditálásának eszközévé vált. Ez majdnem olyan káros, mint a kritikátlan elfogadás.

Láthatóan tisztában van ezzel a Németországi Tudományos Orvosi Társaságok Egyesülete (AWMF) is. Az orvosi kutatás teljesítményének értékeléséről kiadott brosúrájukban [20] a DORA aláíróiként természetesen teljes egyetértésüket fejezik ki az abban foglaltakkal; hosszabb paragrafusokat szó szerint is átvesznek belőle. A tudománymetriai mutatószámokat illetően azonban hozzáteszik: „Ezeknek a mutatószámoknak bizonyítékokon alapulónak, átláthatóaknak és kivitelezhetőeknek kell lenni. A mutatószámok bizonyított tapasztalati háttere meg kell, hogy feleljen az értékelés céljának. Az egyszerüség nem lehet a fó kritérium, ez nem vezethet alkalmatlan eszközök használatához. [...] Módszertanilag adekvát értékelések készítéséhez szükség esetén tudománymetriai szakértőket kell 'megvásárolni'.” Az egyéni értékeléseket illetően Glänzel és Wouters tanácsait [21] ajánlják iránymutatónak. Magam sem tudok jobbat. Zárszóként tőlük idézem a cikk témájába vágó tanácsot:

„A 'Ne tedd!' tételek sem tabuk, ha megfelelően alkalmazzuk őket. Nincs okunk kárhoztatni a gyakran helytelenül használt impaktfaktort vagy h-indexet. Értékes kiegészítő információkat szolgáltathatnak, ha kvalitatív módszerekkel kombinálva használjuk őket és nem egyedüli döntési kritériumként."

\section{Köszönetnyilvánítás}

Köszönöm Prof. Dr. Sarkadi Balázsnak, hogy felhívta a figyelmemet a téma időszerűségére és fontosságára.

Anyagi támogatás: A szerző köszöni az FP7-SSH-2013-2 \#613202 (IMPACT-EV) projekt támogatását.

A cikk végleges változatát a szerző elolvasta és jóváhagyta.

Érdekeltségek: A szerzőnek nincsenek érdekeltségei.

\section{Irodalom}

[1] Lukács, G.: Béla Balázs and those who do not like him. Collected studies. [Balázs Béla és akiknek nem kell. Összegyújtött tanulmányok.] Kner, Gyoma, 1918. [Hungarian]

[2] Schubert, A.: The impact factor and those who dislike it. [Az impakt faktor és akiknek nem kell.] MTAK-TTO szeminárium, Budapest, 2012. http://www.mtakszi.iif.hu/docs/esemenyek/ ImpaktFaktor_SA.pdf [Hungarian]

[3] Garfield, E.: Citation indexes to science: a new dimension in documentation through association of ideas. Science, 1955, 122, 108-111.

[4] Garfield, E.: Citation analysis as a tool in journal evaluation. Science, 1972, 178, 471-479.

[5] Seglen, P. O.: Why the impact factor of journals should not be used for evaluating research. British Medical J., 1997, 314, 498502.

[6] Opthof, T.: Sense and nonsense about the impact factor. Cardiovasc. Res., 1997, 33, 1-7.

[7] Moed, H. F., Van Leeuwen, T. N.: Improving the accuracy of In stitute for Scientific Information's Journal Impact Factors. J. Am. Soc. Inform. Sci., 1995, 46, 461-467.

[8] Hecht, F., Hecht, B. K., Sandberg, A. A.: The journal "impact fac tor": a misnamed, misleading, misused measure. Cancer Genet. Cytogenet., 1998, 104, 77-81.

[9] Vinkler, P.: Publication velocity, publication growth and impact factor: An empirical model. In: Cronin, B., Atkins, H. B. (eds): The Web of Knowledge, A Festschrift in Honor of Eugene Garfield. ASIS Monograph Series. Information Today, Inc., Medford, New Jersey, 2000.

[10] Pinski, G.: Subject Classification and Influence Weight of 2300 Journals. Computer Horizons, Inc., Cherry Hill, 1975.

[11] Noma, E.: Subject Classification and Influence Weights for 3,000 Journals. NIH Report, Computer Horizon, Inc., Cherry Hill, 1986.

[12] Jacsó, P.: The mirage of prestige. http://www2.hawaii. edu/ jacso/extra/infotoday/prestige/mirage-prestige.htm, 2002.

[13] Jacsó, P.: Péter's Picks \& Pans: Aardvark, JCR on the Web, EuroFactor. Information Today, Inc. - ONLINE Magazine, 2005, 29(6), 54-57.

[14] SCImago Journal \& Country Rank. http://www.scimagojr. $\mathrm{com} /$

[15] Braun, T., Glänzel, W., Schubert, A.: A Hirsch-type index for journals. The Scientist, 2005, 19(22), 8.

[16] Moed, H. F.: Measuring contextual citation impact of scientific journals. J. Informetr., 2010, 4(3), 265-277.

[17] CWTS Journal Indicators. http://www.journalindicators.com/

[18] REF 2014. http://www.ref.ac.uk/

[19] San Francisco Declaration on Research Assessment. http:// www.ascb.org/dora-old/files/SFDeclarationFINAL.pdf

[20] Evaluation of medical research performance - position paper of the Association of the Scientific Medical Societies in Germany (AWMF). http://www.pneumologie.de/fileadmin/pneumologie/downloads/Publikationen /Positionspapier_Evaluation_ der_Forschungsleistung_2014-05-26.pdf

[21] Glänzel, W., Wouters, P.: The dos and don'ts in individual level bibliometrics. Paper presented at the 14th ISSI Conference, Vienna, 15-18 July 2013. http://de.slideshare.net/paulwoutersl/issi2013-wg-pw 